Revue bibliographique pour le domaine irano-aryen

Volume 40-41 | 2019

Comptes rendus des publications de 2017-2018

\title{
Michael Alram, Nikolaus Schindel, Fabrizio Sinisi. „7.1 Iranische Numismatik in vorislamischer Zeit“
}

\section{Rika Gyselen}

\section{(2) OpenEdition \\ 12 Journals}

\section{Édition électronique}

URL : http://journals.openedition.org/abstractairanica/49518

DOI : 10.4000/abstractairanica.49518

ISBN : 1961-960X

ISSN : 1961-960X

Éditeur :

CNRS (UMR 7528 Mondes iraniens et indiens), Éditions de l'IFRI

Référence électronique

Rika Gyselen, « Michael Alram, Nikolaus Schindel, Fabrizio Sinisi. „7.1 Iranische Numismatik in vorislamischer Zeit" », Abstracta Iranica [En ligne], Volume 40-41 | 2019, document 19, mis en ligne le 30 octobre 2019, consulté le 19 avril 2021. URL : http://journals.openedition.org/abstractairanica/ 49518 ; DOI : https://doi.org/10.4000/abstractairanica.49518

Ce document a été généré automatiquement le 19 avril 2021.

Tous droits réservés 


\title{
Michael Alram, Nikolaus Schindel, Fabrizio Sinisi. „7.1 Iranische Numismatik in vorislamischer Zeit"
}

\author{
Rika Gyselen
}

\section{RÉFÉRENCE}

Michael Alram, Nikolaus Schindel, Fabrizio Sinisi. „7.1 Iranische Numismatik in vorislamischer Zeit" in Ludwig Paul (ed.). Handbuch der Iranistik Band 2. Wiesbaden: Reichert Verlag, 2017, p. 74-93

1 Un chapitre du Handbuch der Iranistik Band 2 est consacré à la numismatique iranienne de l'époque pré-islamique. Pour chaque type de monnayage, une introduction générale est fournie (A), puis sont exposés les recherches et nouveaux projets (B) pour se terminer par une bibliographie et les publications les plus récentes (C). Le chapitre est divisé en deux parties selon la position géographique: l'Iran occidental et l'Iran oriental. Chaque grande série monétaire est traitée selon leurs émetteurs: 1. Achéménides; 2. Parthes; 3. Petits états vassaux de l'époque parthe: Elymaïde, Characène / Mésène et Perside ; 4 . Sassanides (l'Iran occidental), et 5. Saces et IndoParthes ; 6. Kouchans et Kouchano-Sassanides ; 7. Huns iraniens et Turks occidentaux ; 8. Choresme et Sogdiane (Iran oriental). 


\section{AUTEURS}

\section{RIKA GYSELEN}

CNRS, Mondes iranien et indien 